\title{
Cannabis sativa-An Important Subsistence Pollen Source for Apis mellifera.
}

\author{
Dr. Jasvir Singh Dalio \\ Street No.12 Yog Nagar, Budhlada -151502, \\ Distt. Mansa, Punjab, India \\ Email-drjasvirdalio@gmail.com.
}

\begin{abstract}
Cannabis sativa is an important source of pollen for Apis mellifera during the period of floral scarcity (May and June) when major flora is absent. Foraging of bees on the herb under experiment took place during morning and evening hours, while during rest of the day activity remained totally ceased. All the Foraging bees were pollen gatherers as the plant provides pollen only. Maximum foraging took place during morning, however pollen was also collected thoroughly by specific sweeping activity and scrabbling behaviour during evening hours. Foraging frequency of bees was more during morning as compared to that at evening. Average pollen load observed was $4 \mathrm{mg} / \mathrm{bee}$. Abundance, Foraging behaviour and pollen loads indicated that this annual herb in good source of pollen during dearth period in summer.
\end{abstract}

Keywords: Apis mellifera , cannabis sativa, foraging behaviour of A. mellifera, pollen.

\section{INTRODUCTION}

For successful beekeeping it is desirable to know availability suitability and identification of minor and subsistence flora during dearth period, which is possible by studying foraging behaviour of honeybees on such type of flora. One of the major problems in beekeeping is the presence of floral dearth periods and there is hardly any locality where major bee flora is available round the year. This results in dwindling and desertion of bee colonies. Large number of minor and subsistence sources serve the important purpose of build up or sustaining bee colonies. In Punjab, May and June is a period of floral scarcity (dearth period). Most of beekeepers have to provide sugar syrup and pollen substitute to bee colonies. Pollen is of great importance for bee colonies as it is good source of proteins, lipids, minerals and vitamins required for the growth and development of brood, newly emerged bees and is essential for workers to secrete royal jelly. Availability of enough pollen directly helps gradual colony build up.

There are many weeds from which honeybees collect nectar, pollen or both. However their number per unit area is less or having lesser quantity of pollen or nectar. These minor sources are utilized by bees during the time of scarcity of major bee flora. At such critical time cannabis sativa in very useful for honey bees.

Cannabis sativa is a robust, tall growing, highly competitive, annual, herbaceous, dioecious and wild plant which grows all over India but very common in Punjab on non-crop land area (along the sides of roads, railway tracks, canals, vacant plots, moist farmyards etc. ) and is now introducing in Orchards and field crops. Male plants are very common as compared to female plants. [1] . Honeybees cannot collect pollen or nectar from every type of flower but more abundance of honeybees for pollen collection on this herb has been reported by many workers earlier. [2,3 and 4].

Detailed information regarding weeds as bee flora in various agroclimatic zones is very scanty. This study will help to know foraging behaviour of Apis mellifera on cannabis sativa and importance of this weed as a pollen source in dearth period.

\section{Materials And Methods}

Uncultivated waste land with densely growing cannabis sativa, near Budhlada (Longitude $75^{\circ}-34^{\prime}-00^{\prime \prime}$ E, Latitude $29^{\circ}-55^{\prime}-00^{\prime \prime} \mathrm{N}$ and elevation above sea level is 219 meter) in district Mansa (Punjab), having already running apiary of Apis mellifera nearby, was selected for study. Experiments were conducted during full blooming season of this weed (May and June) in year 2011. Abundance of A. mellifera bees was observed by counting number of foraging bees $/ \mathrm{m}^{2} / \mathrm{min}$ on randomly marked plots of one square meter of this weed. Observation were taken after every 30 minutes starting from 610 to 740 hours on each alternating day for 30 days. On remaining alternating days, foraging frequency (number of flowers visited $/ \mathrm{min}$ ) was recorded with help of stop clock, at selected hours of the day. Data of windy days was recorded separately. On randomly selected days, A. mellifera bees with full pollen loads were captured with help of forceps during full foraging activity. Pollen loads were removed from their pollen baskets with help of camel hair brush in watch glass and weighted with help of electronic balance. General observations of foraging bees, emerging bees, adult bees in the hive as well as of brood, were taken while consuming pollen of this plant to note any adverse effect as 
certain parts of the Cannabis sativa are well known for their narcotic properties .Collected data was consolidated and results were drawn.

\section{RESULTS AND DISCUSSION}

Apis mellifera bees commenced their foraging activity on cannabis sativa "Fig 1" early in the morning at 610 hours and foraged only during morning (610 to 1010 hours) and evening (1640 to 1940 hours) time. Foraging activity on weed under investigation remained totally ceased from 1040 to 1610 hours. On an average 3.667 and 2.000 bees per square meter of this blooming weed per minute were recorded during morning and evening hours, respectively.

All the bees observed were pollen gatherers as these plants provided pollen only. Only pollen foraging from this plant has already been confirmed by many workers [2,3,4 and 5].On an average number of bees $/ \mathrm{m}^{2}$ / min were found to be $6,7,6,3,3,3,2,2,1,1,2,2,2,3,3,1$ at $610,640,710,740,810,840,910,940,1010$, $1640,1710,1740,1810,1840,1910$ and 1940 hours respectively. A clear peak in foraging activity of honeybees was observed between 610 to 710 hours $\left(7 \mathrm{bees} / \mathrm{m}^{2} / \mathrm{min}\right.$ ). A peak during evening hours, though of low magnitude was also observed at 1840 to 1910 hours ( $3 \mathrm{bees} / \mathrm{m}^{2} / \mathrm{min}$ ). These observations are in line with conclusions drawn by Brar et al [6] in case of Pigeon pea (Cajuns Cajan L.)

Maximum foraging of pollen during morning hours has also been confirmed on various crops by many worker [7,8,9 and 10]. Reason of maximum pollen foraging during morning is that dehiscence of anthers takes place at appropriate time of the day, which is characteristic of a plant species, then flowers have copious pollen, accordingly bees regulate their activity for pollen collection [11]. Other factors like time related physiology of plants, environmental factors and innate responses of honeybees are also responsible for peak foraging. Weather particularly temperature (hours of day) determine bee foraging activity directly or indirectly.

Flower sweeping activity and scrabbling behaviour of bees to collect pollen was observed during evening hours. They collected pollen from broken anthers of flowers and even try to bite anthers for pollen collection. Bees tended to explore flowers very thoroughly. This behaviour is due to less quantity of pollen in flowers at evening time but higher colonial demand for it due to dearth period. Such typical scrabbling behaviour by pollen seeking bees on some other crops has been reported earlier [12]. Hours of day dictate bee activity directly and also indirectly through availability of pollen and nectar. Need of colony is basic determining factor for bee foraging [13,14 and 15].

Average number of flowers visited /min. during morning time was more ( $6.667 \mathrm{flowers} / \mathrm{min})$ as compared to that during evening hours (4flowers/min). Foraging frequency becomes very low during evening hours. Foraging rate decreased during evening because anthers got broken and bees showed scrabbling behaviour or sweeping movement for pollen collection. Foraging Frequency (Number of flowers visited/min) depends upon number of factors including instinctive foraging behaviour of insects, floral structure [16 and 17], nature of floral rewards, density of flowers and environmental factors. Decreasing of foraging rate was recorded with increasing velocity of wind. These results has also been confirmed by many worker [18,19 and 20].

Average pollen load recorded was $4 \mathrm{mg} / \mathrm{bee}$. The size and weight of pollen load differed greatly with different crops and bee species. [21,22,23,24,25 and 26].No adverse effect of pollen of the plant under experiment was noted on adult bees and larvae of A. mellifera, however certain parts of Cannabis sativa plant (especially leaves) are wall known for narcotic properties.

From abundance of foraging bees, foraging behaviour and pollen loads, it may be concluded that Cannabis sativa is good source of pollen for bees. This herb provided pollen to A. mellifera at the time of highly scarcity of bee flora (May and June). As pollen shortage is disastrous to the bee colony and one comb cell of pollen is required for rearing one larva [27]. Therefore this weed is of considerable importance for A. mellifera and hence for beekeeping. Availability of such flora is useful for the subsistence of bee colonies during dearth period. This study will help to provide guidelines to make local floral calendar, standardizing the seasonal management practices for apiculture and recognization of Cannabis sativa as subsistence honey bee flora.

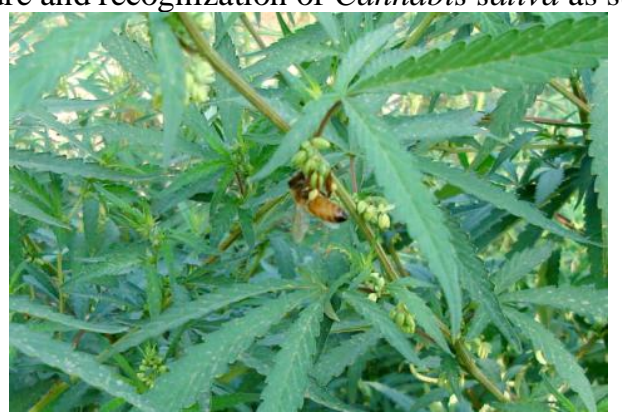

Fig.1 Apis mellifera foraging on Cannabis sativa flower 


\section{References}

[1] U.S. Walia and R.S.Uppal, Weeds, in A.P. Singh, (Ed.), field Problems of fruit crops, (Foil Printers, Ludhiana,India, 2004), 230. 188 239.

[2] O.P. Sharma and D.Raj, Diversity of bee flora in Kangra Shivaliks and its impact on beekeeping. Indian Bee J. 47, 1985, 21-24.

[3] H.K. Sharma and J.K. Gupta, Diversity and density of bee flora of Solan region of Himachal Pradesh (India) Indian Bee. J. 55(1/2), 1993, 9-20.

[4] D.P. Abrol, Food of the honey bees, bee flora and honey flow periods. in D.P. Abrol (Ed), Bees and beekeeping in India. (Kalyani Publishers Ludhiana Inida 1997), 108 - 151.

[5] S. Singh, Bee Pasturage in A.M. Wadhwani, (Ed.) Beekeeping in India, (Indian Council of Agricultural Research, New Delhi,1962). $92-123$.

[6] H.S. Brar, G.S. Gatoria and B.S. Chahal,Bee Flora of Punjab, its relative utility and calendar of availability of honeybees. Indian J.Ecol.16(2), 1989, 159-163.

[7] A.K.Thakur, O.P. Sharma, R. Garg and G.S. Dogra, comparative studies on foraging behaviour of Apis mellifera and A. cerana indica on mustard. Indian Bee J., 44, 1982, 91-92.

[8] A.S.Tanda, Foraging behaviour of three species of Apis on raya in relation to sugar concentration in its nector. Indian Bee J., 46, 1984, 5-6.

[9] G.D. Waller, J.O. Moffett, G.M. Loper and J.H.Martin, An evaluation of honeybee foraging activity and pollination efficiency for male sterile cotton. Crop. Sci., 25, 1985, 211-214.

[10] Verma and Dulta.. Foraging behaviour of Apis cerana indica and Apis mellifera in pollinating apple flowers. J. Apic. Res. 25(4), 1986, $197-201$.

[11] A.S. Atwal, Essentials of beekeeping and pollination (Kalyani Publishers, Ludhiana India, 2000).

[12] Doull, M Keith An analysis of bee behaviour as it relates to pollination American Bee Journal 111 1971,266.

[13] A.D. Synge, Pollen collection by honeybees (Apis mellifera). J. Anim. Ecol., 16, 1947, 122-138.

[14] C.R. Ribbands, The behaviour and social life of honeybees, (London. IBRA: Dover Publication inc. N.Y. ,1953).

[15] M.S. Percival,.Flora biology. (Oxford, Pergamon press, 1965).

[16] J.B. Free, Insect pollination of crops, (London, U.K.: Academic Press1970),

[17] F.S. Gilbert, Flowers visiting by hoverflies (syrphidae) Ann. Rev. Eccl and Syst., 6, 1980,139-170.

[18] G.F. Wilson, Insect visitors of Fruit blossoms. J. Res. Hort. Soc., 51, 1926, 225-251.

[19] G.F. Wilson, Pollination of hardly fruit insect visitors of fruit blossoms. Ann. Appl. Biol., 16, 1929, 02-629.

[20] J.B. Free, The behaviour of honeybees visiting the flowers of fruit trees. J. Anim. Ecol.,29, 1960, 385-395.

[21] O.W. Park, Time and labour factors involved in gathering pollen and nectar. Am. Bee. J., 62, 1922, 254-255

[22] R.L. Parker,The collection and utilized of pollen by the honeybees. Mem. Cornell agric. Expt. Stn., 98, 1936, 1-55.

[23] F.Lukoschus, Quantitative untersuchungen uber den pollen transport in Haarkteid der Honigbiens. A. Bienenforsch, 4, $1957,3-21$.

[24] N.D. Skrebtsova, Pollination of buckwheat flowers by bees. Pchelovodstvo, 34(9), 1957, 48-50.

[25] A.A. Punjabi, S.K. Saraf and G.Singh, Studies on pollen carring capacity of the hill strain of the Indian honey bee: Apis Indica F. in Kashmir, in relation to its body weight. Indian Bee J., 31(1), 1969, 9-11.

[26] G.S. Dhaliwal, Observations on the pollen carring capacity of Apis indica and Apis mellifera L. Indian J. Ent., 32(1), 1970, 173.

[27] R.C. Mishra and S.K. Sharma, Technology for management of Apis mellifera in India, in R.C. Mishra, (Ed.), perspectives in Indian apiculture, (Agro Botanica, Bikaner India, 1998)131-147. 